\title{
Economic or cultural backlash? Rethinking outsiders' voting behavior
}

Fedra Negri, Dept. of Social and Political Sciences, Università degli Studi di Milano

Electoral Studies, Volume 59, June 2019, Pages 158-163

Doi: https://doi.org/10.1016/j.electstud.2019.02.009

\begin{abstract}
Political economists show that outsiders (unemployed and temporary workers) support redistributive policies more than insiders (standard dependent workers) and infer outsiders' voting behavior from their desired degree of State intervention in the economy. However, it has been suggested that international interdependence is reshaping the political space along two dimensions: the traditional economic left-right scale, and an emerging cultural integration-demarcation dimension. How do outsiders behave in this two-dimensional political landscape? This research note answers this question by combining individual data from the latest five waves of the European Social Survey (2008-2016) with party positions provided by the Comparative Manifesto Project on 27 European countries. Integrating research based on party families with parties' policy positions, results show that the economic State-market dimension is still more linked to outsiders' voting behavior than the cultural integration-demarcation dimension.
\end{abstract}

Keywords: outsiders-insiders divide; turnout; voting behavior; electoral manifestos; party families.

\section{Introduction}

Since the Partisan Theory (Hibbs, 1977), political economists inferred workers' voting behavior from the desired degree of State intervention in the economy: crudely put, being 
poor and insecure, workers are expected to support major left parties as these are supposedly more likely to implement generous redistributive policies.

However, since the 1980s, the dualization of labor into insiders (i.e., dependent workers hired under permanent contracts) and outsiders (i.e., dependent workers hired under temporary contracts and unemployed people) changed the electoral constituency of major left parties: as famously stated by Rueda $(2005,2006)$, these parties decided to neglect the interests of the outsiders in favor of those of the insiders for electoral reasons. Rueda's hypothesis ignited an exciting debate on the vote choice of outsiders (e.g., Rovny and Rovny, 2017; Bürgisser and Kurer, 2016; Marx, 2014; Marx and Picot, 2013): empirical literature in this field displays a high degree of accumulation and sophistication, but the results still cannot reach a satisfactory convergence.

More recently, political scientists suggested an alternative scenario in which the role of the economic dimension in shaping voting behavior is downplayed in favor of a cultural dimension (Kriesi et al., 2006). Scholars argued that the globalization process is reshaping the political space along two dimensions: the traditional economic left-right scale, and a new emerging cultural integration-demarcation dimension. Along with the first dimension, individuals and parties with leftist, pro-State intervention and egalitarian policy positions are confronted with those with rightist, pro-market and anti-egalitarians policy positions. Instead, the second dimension puts individuals and parties with a cosmopolitan view of society against those mobilizing in defense of national identities and communities (Grande and Kriesi, 2012). How do outsiders behave in this new twodimensional political landscape?

This research note engages with this debate by combining individual data from the latest five waves of the European Social Survey (2008-2016) with party positions provided by the Comparative Manifesto Project on 27 European countries (MRG/CMP/MARPOR: 
Volkens et al., 2018a). It contributes to the existing studies because it reclassifies the party voted by each respondent at the latest national election along its signaled preferences on the two aforementioned dimensions (i.e., State-market and integrationdemarcation dimensions).

This move represents a meaningful improvement. Indeed, from a methodological point of view, it allows to take gradual differences on key policy dimensions among parties with a great amount of precision (Schwander, 2018; Döring and Schwander, 2015). From a substantive point of view, it allows to investigate, even if within a correlational research design based on observational data, the reasons behind outsiders' party choices.

The note is structured as follows. Section 2 recalls the hypotheses formulated so far on outsiders' voting behavior and enucleates the contribution of this study. Section 3 describes the dataset and the operationalization of the main variables. Section 4 hosts the empirical analysis. The last section highlights the main findings and suggests paths for future research.

\section{Outsiders' voting behavior}

\subsection{State of the art}

Over the last decades, several studies demonstrated that individuals facing high levels of labor market marginalization are more likely to favor redistributive policies as they search protection from future income losses (e.g., Gingrich and Häusermann, 2015; Häusermann et al., 2015; Häusermann and Schwander, 2011). This empirical regularity grounded the basic prediction of the Partisan Theory (Hibbs, 1977), according to which such marginalized workers constitute the electoral constituency of major left parties, usually social-democratic ones. 
However, with his seminal works, Rueda $(2005,2006)$ paved the way to a different scenario. He suggested that, since the 1980s, the dualization of labor forced major left parties to choose between the insiders and the outsiders. As the former are usually more engaged in politics (e.g., Marx and Nguyen, 2016) and outnumber the latter (Saint-Paul, 1996: 266), major left parties became the advocates of insiders only.

However, if outsiders are no more expected to vote for major left parties, how will they behave at the election time? Results uncover a still limited consensus (for a systematic review, see: Schwander, 2018).

On the one hand, political sociology suggested that outsiders are more likely to withdraw from politics (Lim and Sander, 2013; Burden and Wichowsky, 2014; Marx and Nguyen, 2016). Economic hardship is usually the main driver: individuals are so afraid by everyday job-related financial worries that they do not have additional time and cognitive resources to devote to political participation (Mani et al., 2013). Moreover, the workplace is described as a training site for political discussion, information and recruitment (e.g., Anderson, 2010). Furthermore, labor market failures are expected to lower individuals' sense of mastery, thus decreasing their perceptions of political efficacy (Beaumont, 2011). Studies in this field mainly focused on the unemployed and largely documented a negative correlation between unemployment and political participation (Rovny and Rovny, 2017; Marx and Nguyen, 2016; Burden and Wichowsky, 2014). However, starting from Gallego (2007), the scope of this strand of literature has been extended to vulnerable employment, with mixed findings.

On the other hand, when outsiders turnout, which parties do they vote for? Rueda (2005: 62, 2006) argued that major right parties (i.e., liberal, conservative and Christian democratic parties) may be appealing as they are more likely to decrease the level of employment protection legislation. This option has immediately been judged as 
problematic because major right parties are also more likely to decrease unemployment benefits and to raise the retirement age, policy proposals that hardly correspond to outsiders' interests (Emmenegger, 2009). A recent comparative study on 17 western European countries from 2002 to 2010 (Rovny and Rovny, 2017) found that outsiders are indeed less likely to vote for major right parties than insiders. Similar results have been provided on the case of Germany in 2009 (Marx and Picot, 2013).

Alternatively, outsiders have been described as likely voters of 'other' left parties, which do not belong to the social-democratic family. These parties are mainly new left and ecologist parties. They are expected to be more attractive for outsiders as they 'favor a strong welfare state, but a different kind of welfare state', which is seen as more universalistic (Schwander, 2018). This hypothesis has been confirmed by several studies (Marx and Picot, 2013; Marx, 2014; Emmenegger et al., 2015).

Lastly, this stream of literature has recently built a bridge towards the one on the political behavior of 'globalization losers' (Kriesi at al., 2006). Crudely put, international interdependence is fostering the emergence of a new politically salient cleavage, the socalled integration-demarcation cleavage, which pits winners against losers of globalization (Kriesi at al., 2006). This cleavage has reshaped the political space along two dimensions (Grande and Kriesi, 2012). The first corresponds to the traditional proState/pro-market dimension. The second dimension sets individuals and parties with a cosmopolitan view of society against those mobilizing in defense of homogeneous national identities.

How are outsiders expected to behave in this reshaped political landscape? Empirical investigations suggest that unemployed individuals and unskilled workers in traditionally protected sectors may vote for radical right parties, usually adopting a populist rhetoric, as these parties blame the process of globalization for job losses at the national level 
(Georgiadou et al., 2018; Nicoli, 2017; Hernandez and Kriesi, 2016; King and Rueda, 2008). Moreover, this 'economic backlash' may interact with a 'cultural backlash' that sees migrants as rivals in the labor market and aliens from a cultural point of view (Sniderman et al., 2004), further rewarding radical right parties as they support welfare chauvinism (Ennser-Jedenastick, 2018, Otjes et al., 2018).

It is possible to summarize the expectations reviewed so far as follows:

H1: Outsiders are more likely to abstain from voting than insiders.

H2: Outsiders are less likely to vote for major left parties than insiders.

H3: Outsiders are more likely to vote for 'other' left parties (i.e., (former) communist, new left and ecologist parties) than insiders.

H4: Outsiders are more likely to vote for major right parties (i.e., liberal, conservative and Christian democratic parties) than insiders.

H5: Outsiders are more likely to vote for radical right parties than insiders.

\subsection{An empirical contribution}

This research note contributes to the existing studies by establishing a direct link between respondents' labor market status and parties' policy positions on the State-market and the integration-demarcation dimensions.

This is a meaningful methodological improvement as looking only at party families may be potentially misleading (Schwander, 2018; Döring and Schwander, 2015). In fact, quoting Häusermann, Picot and Geering (2013: 239), 'Parties may still have the same names as thirty or forty years ago, but that may not tell us much about their voter profile anymore' because they may have changed their positions over the right-left spectrum and, thus, their policy proposals. 
For example, the French Socialist Party remarkably shifted its position on the ideological left-right dimension along its history. In the 1973 election, it scored -41 on the wellknown Rile scale (-100 extreme left, +100 extreme right: Laver and Budge, 1992). Then, over the 1990s, it moderated its stances: it scored -13 in the 1997 election and -16 in the 2002 election. Very recently, it seems on its way back to the original leftist position: it scored -29 in the 2017 election.

Even focusing only on the last years, the same party family may embed parties with highly heterogeneous policy stances. For example, the social-democratic party family embeds the Slovenian Social Democratic Party, which in the 2011 election scored -1 on the Rile scale, thus locating at the center of the ideological spectrum, the Swedish Social Democratic Labor Party, which scored -52 in the 2014 election, and the Swiss Social Democratic Party, that scored -64 in the 2011 election (MRG/CMP/MARPOR: Volkens et al., 2018a).

This research note suggests integrating the mainstream party-family approach with the quantitative content analysis of party manifestos as it promises more fine-grained insights into outsiders' voting behaviors. In fact, this move allows to directly test the following hypotheses:

H6: Outsiders are more likely to vote for parties with pro-State intervention and egalitarian policy positions than insiders.

H7: Outsiders are more likely to vote for parties defending national identities and communities.

The hypotheses 1-7 abruptly compare outsiders to insiders. However, it is common knowledge that the outsider group is highly heterogeneous (Emmenegger, 2009) as unemployed individuals occupy a worse position compared to the one of temporary workers. Beside these two well-established groups, a new category of workers is entering 
the outsiders' world: namely, self-employed individuals without employees (labelled 'solo self-employed': Jansen, 2016). This new category deserves attention because of its 'Janus face'. On the one hand, as potential (future) employers, they may reward rightwing parties because they may benefit from flexible labor markets and low levels of social protection. On the other hand, being exposed to risks comparable to the ones of temporary employees, they may reward left-wing parties because they need social protection. Thus, comparing the political behavior of unemployed people, temporary workers and solo selfemployed to the one of insiders seems promising.

\section{Data description and case selection}

The analysis is performed on two merged data-sources: the latest five waves of the European Social Survey (ESS rounds 4-8), collected between 2008 and 2016, and the Manifesto Project Dataset (MRG/CMP/MARPOR: Volkens et al., 2018a).

The sample includes 27 European countries: Austria, Belgium, Bulgaria, Croatia, Czechia, Denmark, Estonia, Finland, France, Germany, Greece, Hungary, Ireland, Italy, Latvia, Lithuania, the Netherlands, Norway, Poland, Portugal, Romania, Slovakia, Slovenia, Spain, Sweden, Switzerland and the United Kingdom.

Given the theoretical focus, the sample is restricted to the workforce (i.e., employed and unemployed respondents actively searching for a job). Students, retirees, homemakers, the permanently sick or disabled, those in military service and those above the age of 67 years are excluded. Similarly, being interested in voting behavior, respondents below the age of 18 years are excluded. The resulting sample includes 64901 individual respondents in 27 countries across 9 years.

\subsection{Dependent variables}


The analysis develops into two steps. First, the hypotheses H1-H5 are tested through a categorical dependent variable that recodes the party voted by each respondent at the latest national election according to the party family classification provided by MRG/CMP/MARPOR (Volkens at al., 2018a). It distinguishes among 1. Abstention; 2. Ecologist Parties; 3. (Former) Communist Parties, 4. Major Left Parties (i.e. social democratic parties); 5. Major Right Parties (i.e., liberal, Christian democrat, conservative and agrarian parties), 6. Nationalist and Ethnic-Regional Parties and 7. Other (i.e., special issue parties and unclassified cases). The fourth category, Major Left Parties, is set as base category.

Second, the hypotheses $\mathrm{H} 6$ and $\mathrm{H} 7$ are tested by taking advantage of the quantitative content analysis of parties' manifestos performed by MRG/CMP/MARPOR (Volkens at al., 2018a). In detail, the party voted by each respondent at the latest national election has been recoded according to the positions formulated by that same party on the two dimensions suggested by Kriesi et al. (2006).

The dimension State-market is equal to the difference between the percentage of favorable mentions on free market economy (per401, per414) and welfare state limitation (per505), and the percentage of favorable mentions on State intervention in the economic sphere (per403, per404 and per412), welfare state expansion (per504) and social justice (per503). The theoretical range of this scale is -100 (State intervention pole) to +100 (market pole). In our sample, the variable State-market ranges between -63 and +20 . The dimension integration-demarcation is equal to the difference between the percentage of appeals to nationalism (per601), mono-culturalism (per608) and law and order (per605), and the percentage of favorable mentions on cultural plurality (per607) against nationalist stances (per602; Bishof, 2017). The theoretical range for this variable is -100 (integration pole), +100 (demarcation pole). In this sample, it ranges between -23 and 42 . 
Notice that these two variables are weakly correlated $(0.27)$, proving that they point to different underlying dimensions.

\subsection{Explanatory variables}

There are several operationalizations of the insider-outsider dualism. Indicators based on the current labor market status of individuals (e.g., Emmenegger 2009; Lindvall and Rueda 2013; Rueda 2006) highlight the present differences between workers with different contractual positions. Indicators based on occupational categories describe how the future risk of unemployment and vulnerable employment is distributed along a continuum (e.g., Rehm, 2009; Schwander and Häusermann, 2013; see Rovny and Rovny, 2017 for a systematic comparison).

The measure of 'outsiderness' here employed belongs to the first class of indicators. Indeed, respondent's labor market status has been operationalized through five mutually exclusive dummy variables: 1. Insiders (employees under permanent contract - reference category); 2. Temporary workers; 3. Unemployed actively searching for a job; 4. Solo self-employed (without employees) and 5. Self-employed with employees. Being interested in the effect of outsiderness on voting behavior, the analysis mainly focuses on temporary workers and unemployed. However, following a recent development (Jansen, 2016), also the voting behavior of solo self-employed is investigated.

\subsection{Control variables}

The model specifications include the conventional control variables identified in literature (for a comprehensive review: see Marx and Nguyen, 2016): age, age squared, gender (female $=1$ ), household situation (i.e. having a partner and having children), total net household income in deciles, trade union membership, belonging to an ethnic minority, 
and educational level based on the harmonized International Standard Classification of Education (ISCED) categories (low=ISCED 0-2; medium=ISCED 3-4; high=ISCED 5$6)$.

Beside conventional control variables, respondents' attitudes towards redistribution and immigration, their degree of political interest and part-time work have been added.

Respondents' attitudes towards redistribution are measured by levels of agreement on a five-point scale to the statement: 'The government should reduce differences in income levels' ( $1=$ strong disagreement; $5=$ strong agreement $)$.

Similarly, respondents' attitudes towards immigration are measured through the question: 'Would you say it is generally bad or good for [country]'s economy that people come to live here from other countries?' (1=very bad; 5=very good).

The degree of respondents' interest in politics has been assessed through the question: 'How interested would you say you are in politics?' ( $1=$ not at all interested; $4=$ =ery interested).

The dummy variable part-time work is equal to 1 if respondents work less than 30 hours per week. Indeed, previous results suggests that part-time workers are not statistically different from insiders when it comes to turn out to vote, but they are significantly more likely to vote for major right parties then insiders, voting behaviors that seem to distinguish this category from unemployed and temporary workers. In any case, controlling for this variable is important because the ESS does not allow distinguishing between voluntary and involuntary part-time work (Rovny and Rovny, 2017). Descriptive statistics are provided in the online appendix - Table A1.

\section{Statistical analysis}


According to the categorical nature of the first dependent variable, a multinomial logit model predicting seven possible vote choices (1. Abstention; 2. Ecologist Parties; 3. (Former) Communist Parties, 4. Major Left Parties; 5. Major Right Parties, 6. Nationalist and Ethnic-Regional Parties and 7. Other) is used. Major-left parties are set as the baseline category.

Table 1 reports percentage point changes in the probability of abstaining or voting for a given party family when the respondent is unemployed, employee under temporary contract or solo self-employed (instead of being an employee under permanent contract) while the other predictors are held constant (see Table A2 in the online appendix for the full Model 1). Figure 1 displays the same results graphically.

\section{[Table 1 about here]}

In line with $\mathrm{H} 1$, unemployed people and temporary workers have a lower probability to vote than insiders do. The probability of abstaining is $5.3 \%$ points higher for unemployed than for employees under permanent contract. Similarly, the probability of abstaining is $2.2 \%$ points higher for temporary workers than for their permanent counterparts. However, as suggested by the confidence intervals in Figure 1, unemployed people and temporary workers are not statistically different from each other (Wald test: 0.42). Solo self-employed do not behave as outsiders as they do not differ from insiders in their likelihood of voting.

When outsiders cast a vote, which party do they reward? Contrary to the expectation of $\mathrm{H} 2$, major left parties do not seem to be punished by unemployed and temporary workers, whose probability to vote for such parties does not differ from the one of insiders. Instead, solo self-employed manifest a right-wing attitude as their probability to vote for a major left party is $7.3 \%$ points lower than the one of insiders. 
If we look at outsiders' likelihood of voting for the composite category of 'other' left parties, the expectation of $\mathrm{H} 3$ seems not supported by the results. In fact, unemployed people, employees under temporary contract and solo self-employed do not differ from insiders in their probability of voting for a (former) communist party. Moving to ecologist parties, the unemployed are $1.6 \%$ points less likely to vote for them than insiders, while temporary workers and solo self-employed do not differ from insiders.

Contrary to Rueda's expectation (2005) and in line with Emmenegger's one (2009), major right parties, namely liberal, Christian democrats, conservative and agrarian parties, are not particularly rewarded by outsiders. The unemployed are $3 \%$ points less likely to vote for them than insiders, while temporary workers do not differ from insiders. Instead, solo self-employed confirm their right wing attitude: they are $6 \%$ points more likely than insiders to vote for a major right party. Thus, H4 is not confirmed.

Lastly, nationalist and ethnic-regional parties seem far from attracting labor market outsiders as none of the three groups of workers reaches statistical significance (H5).

\section{[Figure 1 about here]}

As previously discussed, these mixed results may be due to the heterogeneity of the parties included in each party family. Thus, the second step of the analysis tests hypotheses H6 and H7 by looking at parties' policy positions on the State-market and integration-demarcation dimensions. These two dependent variables are continuous: they theoretically range from -100 (which means, respectively, pro State intervention and pro cultural integration) to +100 (pro market and pro cultural demarcation). Thus, standard OLS regression are used. Results are reported in Table 2.

\section{[Table 2 about here]}

The results from Model 2 support H6: the estimated coefficients show that outsiders vote for parties located more on the left side of the State-market dimension. Being unemployed 
instead of being under a permanent contract shifts the ideological position of the party chosen at the ballot box of about 1 point to the economic left. Similarly, being under a temporary contract instead of being under a permanent contract shifts the ideological position of the party chosen at the ballot box of 0.6 points to the economic left. Moreover, unemployed and temporary workers are not different from each other according to a Wald test $(\mathrm{p}=0.28)$. Solo self-employed respondents confirm their right-wing party preferences: compared to the parties chosen by the insiders, they vote for parties located 0.9 points towards the economic right. Notice that the party preferences of solo self-employed differ from the ones of self-employed with employees: the latter are indeed significantly more right wing than the former (Wald test: 0.0 ).

Control variables behave as expected. Noticeably, respondents supporting State intervention in the economic sphere tend to vote for parties located on the economic left side of the State-market dimension. The same conclusion can be reached for respondents thinking that immigrants are good for the national economy.

Do outsiders' party preferences on the State-market dimension match those on the integration-demarcation dimension? Estimates from Model 3 suggest a negative answer. Contrary to expectation concerning globalization losers $(\mathrm{H} 7)$, the unemployed tend to vote for parties located 0.4 points towards the integration pole of the integrationdemarcation continuum, while temporary workers and solo self-employed behave exactly as the insiders do. Parties located on the demarcation pole are rewarded only by selfemployed with employees, a result consistent with their overall right-wing attitudes. As expected, respondents more in favor of redistribution and immigration tend to choose parties closer to the integration pole.

\section{Concluding remarks}


This research note contributes to the literature on labor market outsiderness and voting behavior by establishing a clear linkage between respondents' labor market status and the policy profile of the party they voted for on two dimensions: the economic State-market dimension and the cultural integration-demarcation dimension.

As far as outsiders probability to vote is concerned, the results confirm previous findings suggesting that labor market marginalization tend to push the affected individuals outside the political arena (Rovny and Rovny, 2017; Marx and Nguyen, 2016), a result that raises normative concerns.

Moving to outsiders' party choices, this research note takes a leap from recent studies on the voting behavior of globalization losers and investigates two theoretically orthogonal dimensions. Indeed, according to Kriesi et al. (2006), the western political space is becoming two-dimensional: a new integration-demarcation divide stands separate from the traditional economic left-right divide and primarily opposes conservatives believing that national identity should be sheltered from immigration and progressives who favor multiculturalism (Hernández and Kriesi, 2016).

Contrary to this expectation, the results suggest that outsiders' voting behavior are still more linked to the traditional State-market dimension than to the new cultural integrationdemarcation one. Unemployed and temporary workers vote for parties that are more proState intervention and egalitarian than the parties voted by the insiders. Moreover, the results show that respondents' preferences on redistribution are still a strong determinant of vote choice.

Thus, parties' proposals on the economic dimension are crucial for outsiders' party choices. These findings echo studies suggesting that outsiders reward parties promising a more universalistic welfare state (Schwander, 2018). In this regard, in depth qualitative content analyses of parties' manifestos seem promising. 
Instead, outsiderness seems unrelated to culturally conservative policy positions: the parties voted by unemployed and temporary workers do not defend national identities and communities more than the parties voted by the insiders. Even more, the parties voted by the unemployed favor multiculturalism more than the parties voted by the insiders.

These findings promisingly relate to those obtained by investigating outsiders' voting behavior in terms of party families. Indeed, they falsify once more the hypotheses according to which outsiders are less likely to vote for major left parties than insiders (H2) and more likely to turn toward the major (H4) or the extreme right (H6). These two latter families of parties seem unlikely to be rewarded by outsiders since this heterogeneous group of voters pays attention to parties' economic and social policy supply.

Lastly, this study suggest that solo self-employed are not a new entrant category in the outsider group as their party preferences are simply a moderate version of those of selfemployed with employees.

The research note has some limitations though. First, it is based on cross-sectional observational data, which makes it impossible to establish causal relationships. Second, it operationalizes outsiderness according to individual labor market status (Emmenegger, 2009; Rueda, 2006). An alternative approach would have been to classify individuals as outsiders according to their belonging to an occupational group that have an aboveaverage risk of vulnerable employment (Rehm, 2009; Schwander and Häusermann, 2013).

\section{References}

Anderson M. R. (2010). Community psychology, political efficacy, and trust. Political Psychology, 31, 59-84. 
Beaumont E. (2011). Promoting political agency, addressing political inequality: a multilevel model of internal political efficacy. The Journal of Politics, 73, 216231.

Bischof, D. (2017). Towards a renewal of the niche party concept: Parties, market shares and condensed offers. Party Politics, 23(3), 220-235.

Burden B. C. and A. Wichowsky. (2014). Economic discontent as a mobilizer: unemployment and voter turnout. Journal of Politics, 76: 887-898.

Döring, H. and Schwander, H. (2015). Revisiting the Left Cabinet Share: How to Measure the Partisan Profile of Governments in Welfare State Research. Journal of European Social Policy 25: 175-193.

Emmenegger, P. (2009). Barriers to entry: Insider/outsider politics and the political determinants of job security regulations. Journal of European Social Policy, 19 (2): 131-146.

Emmenegger, P., P. Marx, and D. Schraff. (2015). Labor market disadvantage, political orientations and voting: how adverse labor market experiences translate into electoral behavior. Socio-Economic Review, 13 (2): 189-213.

Ennser-Jedenastik, L. (2018). Welfare chauvinism in populist radical right platforms: the role of redistributive justice principles. Soc. Pol. Adm., 52 (1): 293-314.

Gallego, A. (2007). Unequal political participation in Europe. International Journal of Sociology, 37 (4): 10-25.

Georgiadou, V., Rori, L., and Roumanias C. (2018). Mapping the European far right in the 21st century: A meso-level analysis. Electoral Studies, 54: 103-115.

Gingrich, J. and Häusermann, S. (2015). The Decline of the Working-Class Vote, the Reconfiguration of the Welfare Support Coalition and Consequences for the Welfare State. Journal of European Social Policy, 25: 50-75. 
Grande E. and H. Kriesi (2012). The transformative power of globalization and the structure of political conflict in Western Europe. In H. Kriesi, E. Grande, M. Dolezal, M. Helbling, D. Höglinger, S. Hutter and B. Wüest (eds). Political Conflict in Western Europe. Cambridge: Cambridge University Press: 3-35.

Häusermann, S., T. Kurer and H. Schwander. (2015). High-skilled Outsiders? Labor Market Vulnerability, Education and Welfare State Preferences. Socio-Economic Review 13: 235- 258.

Häusermann, S., G. Picot, and D. Geering. (2013). Review Article: Rethinking Party Politics and the Welfare State. Recent Advances in the Literature. British Journal of Political Science 43 (1): 221-40.

Häusermann, S. and Schwander, H. (2011). Varieties of Dualization. Identifying Insiders and Outsiders across Regimes. In Emmenegger, P., Häusermann, S., Palier, B. and Seelieb-Kaiser, M. (eds). The Age of Dualization. The Changing Face of Inequality in Deindustrializing Societies. Oxford: Oxford University Press.

Hernández, E. and H. Kriesi. (2016). The Electoral Consequences of the Financial and Economic Crisis in Europe. European Journal of Political Research 55 (2): 20324.

Hibbs, D. (1977). Political parties and macroeconomic policy. American Political Science Review 71 (4): 1467-1487.

Jansen, G. (2016). Self-employment as atypical or autonomous work: diverging effects on political orientations. Socio-Economic Review. Online first. doi: 10.1093/ser/mww017

King, D. and D. Rueda. (2008). Cheap labor: The new politics of 'bread and roses' in industrial democracies. Perspectives on Politics 6 (2): 279-297. 
Kriesi, H., E. Grande, R. Lachat, M. Dolezal, S. Bornschier and T. Frey. (2006). Globalization and the transformation of the national political space: Six European countries compared. European Journal of Political Research 45: 921-56.

Laver, M. and Budge, I. (1992). Party Policy and Government Coalitions. Houndmills, Basingstoke: The MacMillan Press.

Lim C. and Sander T. (2013). Does misery love company? Civic engagement in economic hard times. Social Science Research, 42, 14-30.

Lindvall, J. and D. Rueda. (2013). The Insider-Outsider Dilemma. British Journal of Political Science First View 1-16.

Mani A. et al. (2013). Poverty impedes cognitive function. Science, 341, 976-980.

Marx, P. (2014). Labor market risks and political preferences: The case of temporary employment. European Journal of Political Research 53 (1): 136-159.

Marx, P. and C. Nguyen, C. (2016). Are the Unemployed Less Politically Involved? A comparative study on Internal Political Efficacy. European Sociological Review 32 (5): 634-648.

Marx, P. and G. Picot. (2013). The party preferences of atypical workers in Germany. Journal of European Social Policy 23 (2): 164-178.

Nicoli, F. (2017). Hard-line Euroscepticism and the Eurocrisis: Evidence from a Panel Study of 108 Elections Across Europe. Journal of Common Market Studies 55 (2): $312-331$.

Otjes, S., Ivaldi, G., Jupskas, R.A., Mazzoleni, O., (2018). It's not economic interventionism, stupid! Reassessing the political economy of radical right-wing populist parties. Swiss Polit. Sci. Rev. https://doi.org/10.1111/spsr.12302.

Rehm, P. (2009). Risks and redistribution: An individual-level analysis. Comparative Political Studies 42 (7): 855-881. 
Rovny, A. and J. Rovny. (2017). Outsiders at the ballot box: operationalizations and political consequences of the insider-outsider dualism. Socio-Economic Review 15 (1): 161-185.

Rueda, D. (2006). Social democracy and active labor-market policies: Insiders, outsiders and the politics of employment promotion. British Journal of Political Science 36 (3): 385-406.

Rueda, D. (2005). Insider-outsider politics in industrialized democracies: The challenge to social democratic parties. American Political Science Review 99 (1): 61-74.

Saint-Paul, G. (1996). Exploring the Political Economy of Labour Market Institutions. Economic Policy 11(23): 265-315.

Schwander, H. (2018). Labor Market Dualization and Insider-Outsider Divides: Why This New Conflict Matters. Political Studies Review. Online first. doi: $10.1177 / 1478929918790872$

Schwander, H. and S. Häusermann. (2013). Who is in and Who is Out? A Risk-Based Conceptualization of Insiders and Outsiders. Journal of European Social Policy 23: $248-269$.

Sniderman, P., Hagendoorn, L., Prior, M. (2004). Predisposing factors and situational triggers: exclusionary reactions to immigrant minorities. Am. Polit. Sci. Rev. 98 (1), 35-49.

Volkens, A., P. Lehmann, N., Matthieß, T.,Merz, N., Regel, S Weßels, B. (2018). The Manifesto Data Collection. Manifesto Project (MRG/CMP/MARPOR). Version 2018a. Berlin: Wissenschaftszentrum Berlin für Sozialforschung (WZB). https://doi.org/10.25522/manifesto.mpds.2018a. 


\section{Tables}

Table 1: Effects of outsiderness on voting behavior - Party families

\begin{tabular}{ll}
\hline Unemployed & \\
\hline Abstention & $0.053 * * *$ \\
Ecologist parties & $-0.016^{* * *}$ \\
(Former) Communist parties & 0.007 \\
Major left parties & -0.018 \\
Major right parties & $-0.031^{* *}$ \\
Nationalist and ethnic-regional parties & -0.003
\end{tabular}

\section{Temporary workers}

\begin{tabular}{ll}
\hline Abstention & $0.022^{*}$ \\
Ecologist parties & -0.007 \\
(Former) Communist parties & 0.006 \\
Major left parties & -0.026 \\
Major right parties & 0.004 \\
Nationalist and ethnic-regional parties & -0.002 \\
\hline Solo self-employed & \\
\hline Abstention & \\
Ecologist parties & 0.011 \\
(Former) Communist parties & 0.013 \\
Major left parties & -0.008 \\
Major right parties & $-0.073^{* * *}$ \\
Nationalist and ethnic-regional parties & $0.059^{* *}$ \\
\hline
\end{tabular}

Notes: Percentage point changes in the probability of abstaining or voting for a given party family according to respondent's labor market status while the other predictors are held constant. Reference category: insiders (see Appendix Table 2 for the full Model 1). 
Table 2: Effects of outsiderness on party choices - Party positions

\begin{tabular}{|c|c|c|}
\hline & State-market & Integration-demarcation \\
\hline & M2 & M3 \\
\hline \multicolumn{3}{|l|}{ (Reference category: insiders) } \\
\hline \multirow[t]{2}{*}{ Unemployed } & $-0.975 * * *$ & $-0.424 * * *$ \\
\hline & $(0.286)$ & $(0.147)$ \\
\hline \multirow[t]{2}{*}{ Temporary worker } & $-0.618 * * *$ & -0.125 \\
\hline & $(0.212)$ & $(0.124)$ \\
\hline \multirow[t]{2}{*}{ Solo self-employed } & $0.899 * * *$ & 0.161 \\
\hline & $(0.227)$ & $(0.123)$ \\
\hline \multirow[t]{2}{*}{ Self-employed with employees } & $2.189 * * *$ & $0.612 * * *$ \\
\hline & $(0.293)$ & $(0.150)$ \\
\hline \multirow[t]{2}{*}{ Pro-redistribution } & $-1.668 * * *$ & $-0.486 * * *$ \\
\hline & $(0.0610)$ & $(0.0344)$ \\
\hline \multirow[t]{2}{*}{ Pro-immigration } & $-0.978 * * *$ & $-0.653 * * *$ \\
\hline & $(0.0519)$ & $(0.0305)$ \\
\hline \multirow[t]{2}{*}{ Part-time worker } & -0.277 & $-0.212 * *$ \\
\hline & $(0.188)$ & $(0.102)$ \\
\hline \multirow[t]{2}{*}{ Interest in politics } & -0.0146 & -0.0450 \\
\hline & $(0.0823)$ & $(0.0476)$ \\
\hline \multirow[t]{2}{*}{ Female } & $-0.475 * * *$ & $-0.485 * * *$ \\
\hline & $(0.128)$ & $(0.0706)$ \\
\hline \multirow[t]{2}{*}{ Age } & -0.0459 & -0.0350 \\
\hline & $(0.0451)$ & $(0.0227)$ \\
\hline \multirow[t]{2}{*}{$\mathrm{Age}^{2}$} & 0.000574 & 0.000335 \\
\hline & $(0.000516)$ & $(0.000257)$ \\
\hline \multirow[t]{2}{*}{ With partner } & 0.198 & 0.0728 \\
\hline & $(0.155)$ & $(0.0807)$ \\
\hline \multirow[t]{2}{*}{ With children } & -0.0654 & 0.0134 \\
\hline & $(0.140)$ & $(0.0729)$ \\
\hline \multirow[t]{2}{*}{ Ethnic minority } & $-1.380 * * *$ & $-0.436 * *$ \\
\hline & $(0.320)$ & $(0.182)$ \\
\hline \multirow[t]{2}{*}{ Trade union member } & $-1.655^{* * *}$ & $-0.435 * * *$ \\
\hline & $(0.139)$ & $(0.0753)$ \\
\hline \multicolumn{3}{|c|}{ (Reference category: low education) } \\
\hline \multirow[t]{2}{*}{ Medium education } & $0.897 * * *$ & $0.246 * *$ \\
\hline & $(0.192)$ & $(0.121)$ \\
\hline \multirow[t]{2}{*}{ High education } & 0.309 & $-0.578 * * *$ \\
\hline & $(0.209)$ & $(0.126)$ \\
\hline Net household income & $0.157 * * *$ & $0.0268 *$ \\
\hline
\end{tabular}




\begin{tabular}{l|ll|}
\hline & $(0.0283)$ & $(0.0161)$ \\
\hline Country dummies & Yes & Yes \\
\hline Wave dummies & Yes & Yes \\
\hline Constant & $-9.114 * * *$ & $8.218 * * *$ \\
\hline & $(1.037)$ & $(0.529)$ \\
$\mathrm{R}^{2}$ & 0.253 & 0.225 \\
$\mathrm{~N}$ & 48444 & 48444 \\
\hline
\end{tabular}

Notes: OLS regressions. Robust standard errors in parentheses. Country and wave dummies included (not shown). ESS population size and design weights applied. ${ }^{*} \mathrm{p}<0.10, * * \mathrm{p}<0.05, * * * \mathrm{p}<0.010$. 


\section{Figure}

Figure 1: Effects of outsiderness on voting behavior - Party families
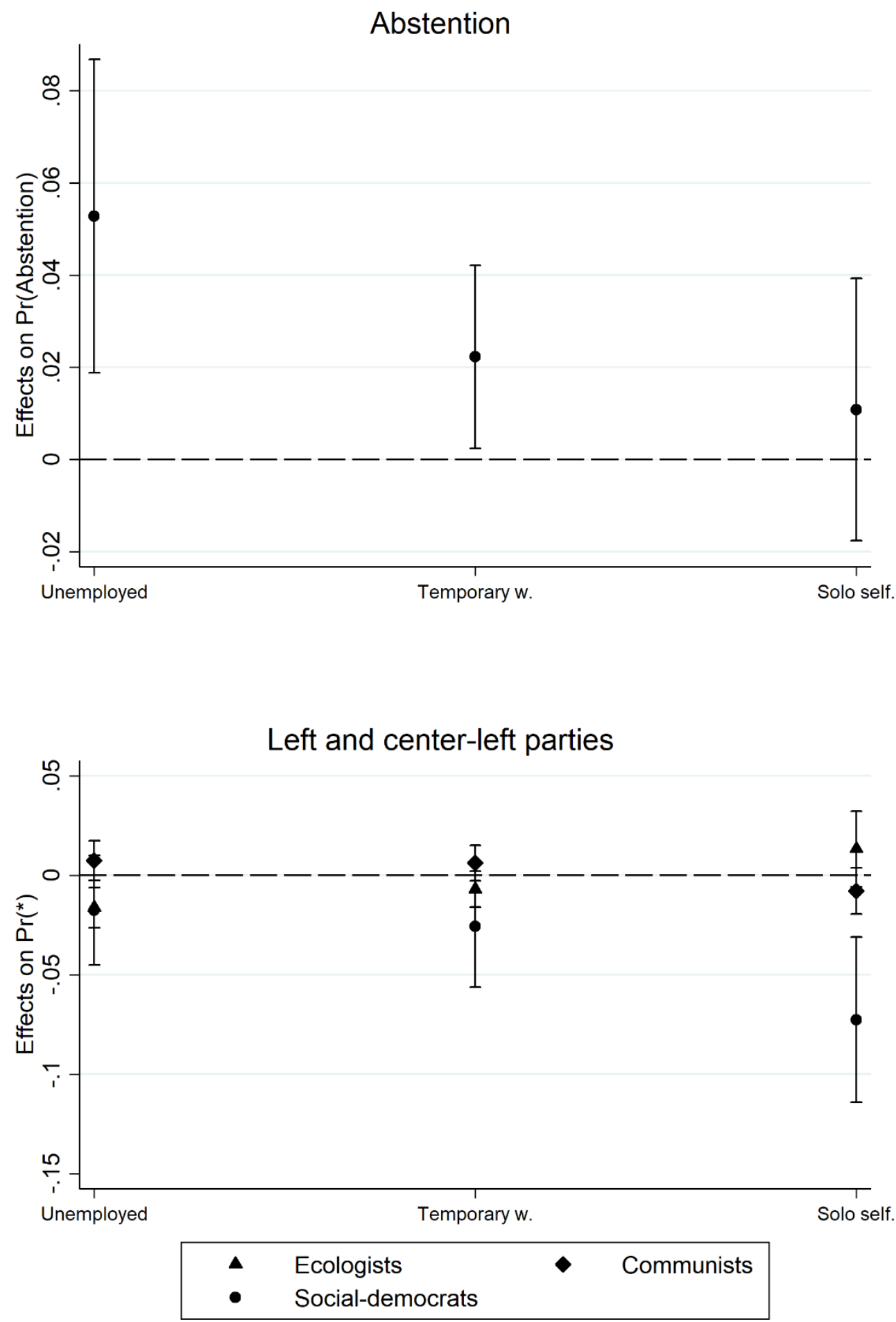
Right and center-right parties

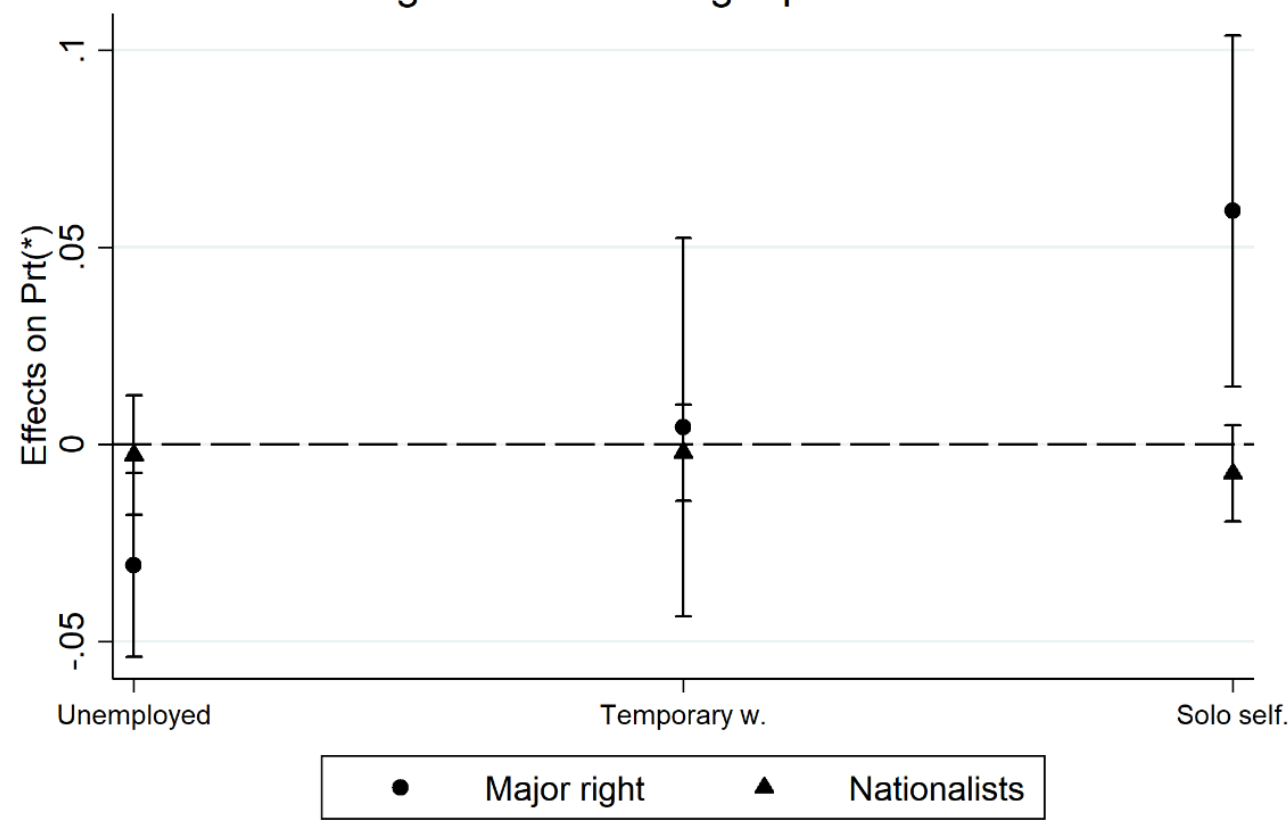

